\title{
PENGARUH MINAT BELAJAR DAN MOTIVASI BELAJAR TERHADAP PRESTASI BELAJAR MATEMATIKA SISWA KELAS VIII SMP NEGERI 22 SINJAI
}

\author{
Suci Auli Asri' ${ }^{1}$, Thamrin Tayeb ${ }^{2}$, Mardiah ${ }^{3}$, \\ St. Ibrah Mustafa Kamal ${ }^{4}$, Ida Suaidah ${ }^{5}$ \\ $1,2,3,4,5$ UIN Alauddin Makassar \\ suciauliaasri98@gmail.com \\ thamrin.tayeb@gmail.com \\ mardhiah.hasan@uin-alauddin.ac.id \\ st.ibramk@uin-alauddin.ac.id \\ idah.suaidah08@gmail.com
}

\begin{abstract}
ABSTRACK
This study aims to determine: (1) a description of the students' interest in learning mathematics at SMPN 22 Sinjai, (2) a description of the motivation to learn mathematics of students at SMPN 22 Sinjai, (3) a description of the mathematics learning achievement of students of SMPN 22 Sinjai.The type of research used is quantitative with the ex post facto method. The sample in this study is the entire population, namely 60 students. The results showed that the students' interest in learning mathematics at SMPN 22 Sinjai was in the medium category. Students' motivation to learn mathematics is in the medium category. Students' mathematics learning achievement is in the medium category. There is a positive relationship between interest in learning and mathematics learning achievement of students at SMPN 22 Sinjai.. There is a positive relationship between learning motivation and student mathematics achievement. Learning interest and learning motivation simultaneously or collectively have a positive relationship to variable $Y$ or learning achievement. That is, the higher the interest in learning and student motivation to learn together, the student achievement will increase, and vice versa.
\end{abstract}

Keywords: learning achievement, learning interest and learning motivation.

\begin{abstract}
ABSTRAK
Penelitian ini bertujuan untuk mengetahui : (1) gambaran minat belajar matematika siswa SMPN 22 Sinjai, (2) gambaran motivasi belajar matematika siswa SMPN 22 Sinjai, (3) gambaran prestasi belajar matematika siswa SMPN 22 Sinjai. Jenis penelitian yang digunakan ini adalah kuantitatif dengan metode ex post facto. Sampel dalam penelitian ini yaitu seluruh populasi yaitu 60 siswa. Penelitian ini menggunakan menggunakan instrumen skala minat belajar dan motivasi belajar serta dokumentasi prestasi belajar matematika siswa SMPN 22 Sinjai. Analisis data yang digunakan yaitu statistik deskriptif dan analisis regresi berganda. Hasil penelitian menunjukkan bahwa minat belajar matematika siswa SMPN 22 Sinjai berada pada kategori sedang. Motivasi belajar matematika siswa berada pada kategori sedang. Prestasi belajar matematika siswa berada pada kategori sedang. Sehingga penelitian yang serupa dapat dilakukan dengan melihat faktor-faktor lain yang memiliki pengaruh terhadap prestasi belajar. Adanya hubungan positif antara minat belajar terhadap prestasi belajar matematika siswa SMPN 22 Sinjai. Adanya hubungan positif antara motivasi belajar terhadap prestasi belajar matematika siswa. Minat belajar dan motivasi belajar secara serentak atau bersama-sama memiliki hubungan positif terhadap variabel Y atau prestasi belajar. Artinya, Semakin tinggi minat belajar dan motivasi belajar siswa secara bersama-sama maka prestasi belajar siswa akan meningkat, dan begitupun sebaliknya.
\end{abstract}

Kata kunci: prestasi belajar, minat belajar dan motivasi belajar. 


\section{PENDAHULUAN}

Pendidikan merupakan usaha sadar untuk mendapatkan pengetahuan, baik secara formal melalui sekolah maupun secara informal dari pendidikan di dalam rumah maupun di masyarakat. Menurut Undang-Undang Sisdiknas No.20 tahun 2003 Pendidikan adalah usaha sadar dan terencana untuk mewujudkan suasana belajar dan proses pembelajaran agar siswa secara akif mengembangkan potensi dirinya untuk memiliki kekuatan spiritual, keagamaan, pengendalian diri, kepribadian, kecerdasan, akhlak mulia, serta keterampilan yang diperlukan dirinya maupun masyarakat (Amin, 2016).

Masalah utama dalam pembelajaran pada pendidikan formal dewasa ini adalah masih rendahnya daya serap siswa. Hal ini tampak dari rerata hasil belajar siswa yang senantiasa masih senantiasa masih sangat memperihatinkan. Di dalam pendidikan hasil belajar merupakan tolak ukur yang paling mendasar, yaitu semakin baiknya hasil belajar yan dicapai dalam dunia pendidikan maka semakin besar kemungkinan tercapainya tujuan pendidikan (Ester, 2017).

Salah satu mata pelajaran yang kurang diminati oleh siswa yaitu pelajaran matematika, di mana matematika merupakan mata pelajaran yang memiliki karakteristik tersediri sebagai ilmu pengetahuan dasar yang mesti diberikan kepada siswa untuk menggiring mereka ke pemikiran yang logis, realistik, kritis, rasional, jujur, efektif dan efesien. Oleh karena itu belajar matematika konsep sangatlah diperlukan. Pembelajaran matematika di sekolah bertujuan untuk melatih cara berfikir dan bernalar dalam menarik kesimpulan dan mengembangkan kemampuan pemecahan masalah. Namun, dalam mempelajari pelajaran harus dengan adanya minat serta termotivasi sehingga dalam mempelajarinya akan menyenangkan sehingga presetasi belajar akan tercapai (Suwarsito, 2017).

Setiap siswa pasti menginginkan prestasi belajar yang baik, begitupun dengan siswa Kelas VIII SMP negeri 22 sinjai, pasti menginginkan prestasi belajar yang baik. Prestasi belajar dapat dilihat dari skor atau nilai yang diperoleh dari evaluasi. Berdasarkan hasil wawancara pada tanggal 22 Juli 2020 oleh ibu Nurhayati Sidiki, S.Pd., di SMP Negeri 22 sinjai mengatakan bahwa minat dan motivasi siswa berbeda-beda setiap individu, ada yang minat dan motivasinya tinggi dan adapula siswa yang minat dan motivasinya terbilang rendah dalam belajar. Namun, kebanyakan siswa minat dan motivasinya tergolong masih rendah dalam pembelajaran matematika. Dapat dilihat dari beberapa siswa masih kebingunan pada materi operasi bilangan yang merupakan dasar matematika yang berkaitan dengan penjumlahan dan pengurangan. Prestasi belajar siswa masih tergolong rendah dapat dilihat dari nilai ulangan semester siswa yang masih kurang memuaskan (Nurhayati, 2020). 
Berdasarkan latar belakang masalah yang telah diuraikan di atas maka penulis bermaksud mengadakan penelitian tentang pengaruh minat belajar dan motivasi belajar terhadap prestasi belajar matematika siswa kelas viii smp negeri 22 sinjai.

Rumusan masalah dalam penelitian ini adalah sebagai berikut: (1) Bagaimana gambaran minat belajar matematika siswa Kelas VIII SMPN 22 Sinjai?, (2) Bagaimana gambaran motivasi belajar matematika siswa Kelas VIII SMPN 22 Sinjai?, (3) Bagaimana gambaran prestasi belajar matematika siswa Kelas VIII SMPN 22 Sinjai?, (4) Bagaimana Model regresi minat belajar terhadap prestasi belajar matematika siswa SMPN 22 Sinjai?, (5) Bagaimana model regresi motivasi belajar terhadap prestasi belajar siswa SMPN 22 Sinjai?, (6) Bagaimana model regresi minat belajar dan motivasi belajar terhadapa prestasi belajar matematika siswa SMPN 22 Sinjai?

\section{TINJAUAN PUSTAKA}

Guru hendaknya berusaha menemukan cara untuk menciptakan kondisi tertentu agar siswa itu selalu butuh dan ingin terus belajar. Dalam artian menciptakan siswa yang mempunyai minat belajar yang besar, mungkin dengan cara menjelaskan hal-hal yang menarik, salah satunya adalah mengembangkan variasi dalam gaya mengajar, dengan variasi ini siswa bisa merasa senang dan mendaparkan kepuasaan terhadap belajar. Selain minat, keberhasilan siswa dalam belajar juga dipengaruhi oleh faktor lain salah satunya motivasi belajar. Motivasi sangat berperan penting dalam keberhasilan belajar siswa, karena motivasi adalah dorongan yang timbul dari dalam diri siswa secara sadar atau tidak sadar yang bisa muncul dari dalam diri sendiri atau dari luar dirinya untuk melakukan tindakan dengan tujuan yang diinginkannya. Motivasi dapat dikatakan sebagai keseluruhan daya penggerak di dalam diri siswa yang menimbulkan, menjamin kelangsungan dan memberikan arah kegiatan belajar, sehingga diharapkan tujuan dapat tercapai. Siswa yang memiliki minat belajar tinggi akan berdsungguh-sungguh belajar karena termotivasi untuk mencapai prestasi (Heriyati, 2017).

Prestasi belajar merupakan gabungan dari dua kata yaitu "prestasi" dan belajar. Setiap kata tersebut memiliki makna tersendiri. Dalam Kamus Besar Bahasa Indonesia, prestasi adalah hasil yang telah dicapai (dari yang telah dikerjakan, dilakukan, dan sebagainya). Prestasi dapat diartikan sebagai hasil yang diperoleh karena adanya aktivitas belajar yang telah dilakukan (Slameto, 2010). Prestasi belajar adalah hasil yang dicapai oleh siswa selama proses belajar mengajar dalam kurun waktu tertentu. (Moh.Zaiful, 2019). prestasi belajar diartikan sebagai tingkat keberhasilan siswa mencapai tujuan yang telah ditetapkan dalam sebuah program pengajaran (Muhibbin, 1995).

Minat belajar adalah perhatian, rasa suka,ketertarikan seseorang (siswa) terhadap belajar yang ditunjukkan melalui keantusiasan, partisipasi, dan keaktifan dalam belajar (Erlando, 2016). Minat adalah suatu rasa suka dan rasa ketertarikan suatu hal atau aktivitas, tanpa ada yang menyuruh dengan kata lain karena kemauan sendiri. Semakin kuat dan dekat hubungan tersebut maka semakin besar rasa ketertarikan kita dengan sesuatu hal (Syaiful, 2002). Minat belajar adalah dorongan- 
dorongan dari dalam diri peserta didik secara psikis dalam mempelajari sesuatu dengan penuh kesadaran, ketengan dan kedisiplinan sehingga menyebabkan individu secara aktif dan senang untuk melakukannya (Kurnia, 2015).

Motivasi belajar adalah perasaan yang muncul pada seseorang yang ditandai dengan perasaan senang, penuh gairah dan penuh semangat dalam belajar (Sardiman, 2012). motivasi belajar dapat timbul karena faktor intrinsik dan ekstrinsik. Faktor intrinsik berupa hasrat dan keinginan untuk berhasil dan dorongan kebutuhan untuk belajar, harapan akan cita-cita. Sedangkan faktor ekstrinsiknya adalah adanya penghargaan, lingkungan belajar yang kondusif, dan kegiatan belajar yang menarik (Hamzah, 2011).

\section{METODE PENELITIAN}

Jenis penelitian yang digunakan dalam penelitian ini adalah penelitian kuantitatif dengan desain penelitian ex-postfacto yang bertujuan untuk mengetahui sebab-akibat serta faktor-faktor yang mempengaruhi penelitian nantinya.

Populasi dalam penelitian ini adalah seluruh Kelas VIII SMP Negeri 22 Sinjai Kab dengan jumlah keseluruhan 60 siswa. Dalam penelitian ini teknik yang digunakan untuk menentukan sampel adalah yang benar-benar dapat mewakili (representative) dan dapat menggambarkan populasi sebenarnya. Maka penelitian mengambil semua populasi sebagai sampelnya. "sensus merupakan titik penentuan sampel bila semua anggota populasi digunakan sebagai sampel.

Data dikumpulkan dengan menggunakan angket dan dokumentasi. Selanjutnya dianalisis menggunakan teknik analisis statistic deskriptif yaitu melakukan kategorisasi data hasil penelitian. Dilakukan juga uji statistik inferensial dengan melakukan analisis sebagai berikut:

1. Analisis Regresi Sederhana dilakukan untuk melihat hubungan variabel bebas (X1) yaitu minat belajar terhadap variabel terikat (Y) yaitu prestasi belajar dengan persamaan regresi.

2. Analisis regresi linier berganda adalah regresi dimana variabel terikatnya (Y) dihubungkan /dijelaskanlebih dari satu variabel, mungkindua, atau tiga, dan seterusnya variabel bebas ( $\left.X_{1}, X_{2}, X_{3}, \ldots X_{n}\right)$ namun masih menunjukkan diagram hubungan yang linier.

\section{PEMBAHASAN}

\section{Deskripsi Minat Belajar Matematika Peserta Didik Kelas VIII SMPN 22 Sinjai}

Hasil dari angket minat belajar siswa Kelas VIII SMPN 22 Sinjai.

Tabel 4.2

Distribusi Frekuensi dan Persentase

Hasil Angket minat belajar siswa Kelas VIII

SMPN 22 Sinjai

\begin{tabular}{|l|l|l|l|}
\hline Interval & Kategori Minat & frekuensi & Persentase \\
\hline
\end{tabular}




\begin{tabular}{|c|c|c|c|}
\hline $57,830 \leq x$ & Tinggi & 8 & $13 \%$ \\
\hline $48,003 \leq x<57,830$ & Sedang & 42 & $70 \%$ \\
\hline$x<48,003$ & Rendah & 10 & $17 \%$ \\
\hline
\end{tabular}

Pada Tabel 4.2 persentase pada interval minat belajar yang paling tinggi adalah pada interval sedang yaitu $70 \%$ apabila siswa kurang paham dengan materi maka siswa akan bertanya kepada gurunya. Hal ini berarti bahwa minat siswa masih berada pada tingkat kategori sedang yaitu sebanyak 42 orang dari keseluruhan siswa. Pada interval rendah dengan presentase yaitu 17\%, dan untuk interval tinggi dengan persentase yaitu 13\%, selisih persentase antara interal tinggi dan rendah yaitu $4 \%$.

\section{Deskripsi Motivasi Belajar siswa Kelas VIII SMPN 22 Sinjai}

Hasil dari angket minat belajar siswa Kelas VIII SMPN 22 Sinjai selanjutnya dikelompokkan dalam tia kategori yaitu motivasi belajar tinggi dengan tabel dan diagram presentase sebagai berikut:

Tabel 4.4

Distribusi Frekuensi dan Persentase Hasil Angket Motivasi Belajar Siswa Kelas VIII SMPN 22 Sinjai

\begin{tabular}{|c|c|c|c|}
\hline Interval & Kategori Motivasi & Frekuensi & Persentase \\
\hline $60,843 \leq x$ & Tinggi & 8 & $14 \%$ \\
\hline $49,757 \leq x<60,843$ & Sedang & 41 & $68 \%$ \\
\hline$x<49,757$ & Rendah & 11 & $18 \%$ \\
\hline
\end{tabular}

Pada Tabel 4.4 berdasarkan persentase pada interval motivasi belajar yang paling tinggi adalah pada interval sedang yaitu $68 \%$ di mana siswa akan lebih rajin belajar apabila mendapat nilai yang memuaskan. Motivasi siswa masih berada pada tingkat kategori sedang yaitu sebanyak 41 orang dari keseluruhan siswa. Pada interval rendah dengan presentase yaitu $18 \%$, dan untuk interval tinggi dengan persentase yaitu $14 \%$, selisih persentase antara interval tinggi dan rendah yaitu $4 \%$. dapat dilihat bahwa masih sedikit siswa yang motivasi belajarnya tinggi.

\section{Deskripsi Prestasi Belajar Matematika Siswa Kelas VIII SMPN 22 Sinjai}

Hasil dari data prestasi belajar matematika siswa Kelas VIII SMPN 22 Sinjai selanjutnya dikelompokkan dalam tiga kategori prestasi belajar tinggi, sedang, rendah dengan tabel dan diagram presentase sebagai berikut:

Tabel 4.6

Distribusi Frekuensi dan Persentase 
Hasil Prestasi Belajar Siswa Kelas VIII

SMPN 22 Sinjai

\begin{tabular}{|c|c|c|c|}
\hline Interval & Kategori Prestasi & Frekuensi & Persentase \\
\hline $85 \leq x$ & Tinggi & 13 & $22 \%$ \\
\hline $74 \leq x<85$ & Sedang & 43 & $72 \%$ \\
\hline$x<74$ & Rendah & 4 & $6 \%$ \\
\hline
\end{tabular}

Pada Tabel 4.6 berdasarkan persentase pada interval prestasi belajar matematika siswa SMPN 22 Sinjai yang paling tinggi berada pada interval sedang yaitu $72 \%$ di mana nilai rata-rata matematika siswa berada pada tingkat kategori sedang yaitu sebanyak 41 orang dari keseluruhan siswa. Pada interval rendah dengan presentase yaitu 6\%, yang artinya memiliki nilai matematika masih berada pada kategori rendah, dan untuk interval tinggi dengan persentase yaitu $22 \%$, yang dimaksud nilai matematika siswa berada pada kartegori tinggi. Selisih persentase antara intevral tinggi dan rendah yaitu $16 \%$, dapat dilihat bahwa masih kurang siswa yang prestasi belajar matematika yang tinggi.

\section{Analisis Regresi Linier}

\section{a. Regresi Linier Sederhana}

1). Persamaan Regresi Linier Sederhana Minat belajar $\left({ }^{X_{1}}\right)$ Terhadap Prestasi Belajar (Y). Berdasarkan hasil pengolahan data menggunakan spp versi 20.0 maka diperoleh nilai a dan b untuk persamaan regresi yaitu:

Tabel 4.7

\section{Koefisien Regresi}

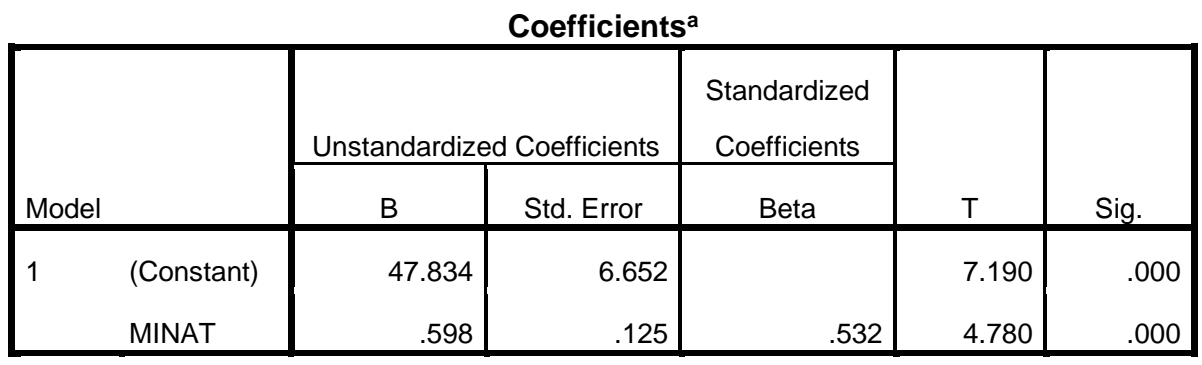

a. Dependent Variable: PRESTASI

Pada Tabel 4.7 di atas diperoleh nilai $\mathrm{a}=47,834$ dan nilai $\mathrm{b}=0,125$ sehingga persamaan regresinya adalah $\mathrm{Y}=47,834+0,98 \mathrm{X} 1$. Dari hasil ini diketahui bahwa minat belajar dan prestasi belajar memiliki hubungan positif karena nilai b lebih besar dari $0(0,598>0)$ yang artinya jika nilai $\mathrm{X} 1$ dinaikkan 1 satuan maka nilai Y akan meningkat sebesar 47,834 satuan.

Tabel 4.8

\section{Koefisien Determinasi}


Model Summary

\begin{tabular}{|l|c|r|r|r|r|}
\hline Model & $\mathrm{R}$ & $\mathrm{R}$ Square & $\begin{array}{c}\text { Adjusted R } \\
\text { Square }\end{array}$ & $\begin{array}{c}\text { Std. Error of the } \\
\text { Estimate }\end{array}$ & Durbin-Watson \\
\hline 1 & $.532^{\mathrm{a}}$ & .283 & .270 & 4.72493 & 2.135 \\
\hline
\end{tabular}

a. Predictors: (Constant), MINAT

b. Dependent Variable: PRESTASI

2). Persamaan Regresi Linier Sederhana Motivasi belajar $\left({ }^{X_{2}}\right)$ Terhadap Prestasi Belajar $(\mathrm{Y})$.

Berdasarkan hasil pengolahan data menggunakan spp versi 20.0 maka diperoleh nilai a dan b untuk persamaan regresi yaitu :

Tabel 4.9

\section{Koefisien Regresi}

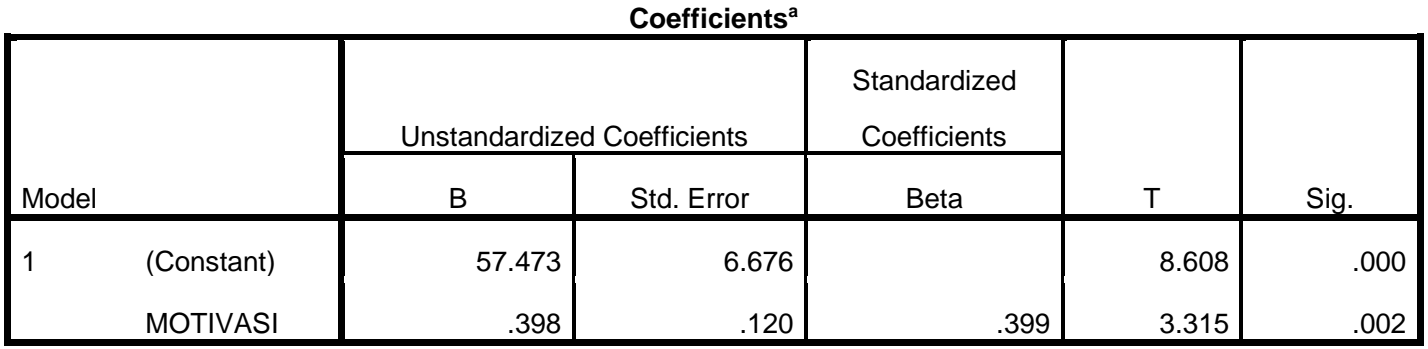

a. Dependent Variable: PRESTASI

Pada Tabel 4.9 di atas diperoleh nilai $\mathrm{a}=57,473$ dan nilai $\mathrm{b}=0,398$ sehingga persamaan regresinya adalah $Y=57,473+0,398 X 1$. Dari hasil ini diketahui bahwa motivasi belajar dan prestasi belajar memiliki hubungan positif karena nilai b lebih besar dari $0(0,398>0)$ yang artinya jika nilai X2 dinaikkan 1 satuan maka nilai Y akan meningkat sebesar 57,473 satuan.

\section{Tabel 4.10}

\section{Koefisien Determinasi}

\begin{tabular}{|c|c|c|c|c|c|}
\hline \multicolumn{6}{|c|}{ Model Summaryb } \\
\hline Model & $\mathrm{R}$ & R Square & $\begin{array}{l}\text { Adjusted R } \\
\text { Square }\end{array}$ & $\begin{array}{c}\text { Std. Error of the } \\
\text { Estimate }\end{array}$ & Durbin-Watson \\
\hline 1 & $.399^{a}$ & .159 & .145 & 5.11491 & 2.100 \\
\hline
\end{tabular}

a. Predictors: (Constant), MOTIVASI

b. Dependent Variable: PRESTASI

\section{b. Regresi Linier Berganda}

Berdasarkan hasil pengolahan data menggunakan spss versi 20.0 maka diperoleh nilai a dan b untuk persamaan regresi sebagai berikut :

\section{Tabel 4.11}

\section{Koefisien Regresi}

\section{Coefficients $^{\mathrm{a}}$}




\begin{tabular}{|c|c|c|c|c|c|c|}
\hline \multirow{2}{*}{\multicolumn{2}{|c|}{ Model }} & \multicolumn{2}{|c|}{ Unstandardized Coefficients } & \multirow{2}{*}{$\begin{array}{c}\text { Standardized } \\
\text { Coefficients } \\
\text { Beta }\end{array}$} & \multirow[b]{2}{*}{$T$} & \multirow[b]{2}{*}{ Sig. } \\
\hline & & B & Std. Error & & & \\
\hline \multirow[t]{3}{*}{1} & (Constant) & 38.301 & 7.643 & & 5.012 & .000 \\
\hline & MINAT & .508 & .127 & .451 & 3.999 & .000 \\
\hline & MOTIVASI & .259 & .113 & 259 & 2.299 & .025 \\
\hline
\end{tabular}

a. Dependent Variable: PRESTASI

pada Tabel 4.11 di atas diperoleh nilai a $=38,301$, nilai ${ }^{b_{1}}=0,508$ dan nilai ${ }^{b_{2}}=0,259$ sehingga persamaan regresinya adala $Y=38,301+0,508 X 1+0,259 \mathrm{X} 2$. Dari tabel tersebut diketahui bahwa:

Hubungan antara variabel bebas X1 yaitu minat belajar dan variabel terikat $\mathrm{Y}$ yaitu prestasi belajar jika variabel bebas X2 motivasi belajar konstan adalah korelasi positif $b_{1}>0(0,508>0)$. Hal ini dapat diartikan bahwa jika nilai X1 dinaikkan sebesar 1 satuan maka nilai Y akan meningkat sebesar 0,508 satuan.

Hubungan antara variabel bebas $\mathrm{X} 2$ yaitu motivasi belajar dan variabel terikat $\mathrm{Y}$ yaitu prestasi belajar jika variabel bebas X1 minat belajar konstan adalah korelasi positif ${ }_{2}>0(0,259>0)$. Hal ini dapat diartikan bahwa jika nilai X1 dinaikkan sebesar 1 satuan maka nilai $\mathrm{Y}$ akan meningkat sebesar 0,508 satuan.

\section{c. Koefisien Determinasi Berganda $\left(R^{2}\right)$}

Koefisien determinasi berganda $\mathrm{R}^{2}$ merupakan ukuran kesesuaian garis regresi linier berganda terhadap suatu data. Koefisien determinasi berganda digunakan untuk mengukur besarnya konstribusi variabel X1 (minat belajar) dan variabel X2 (motivasi belajar) terhadap variabel Y (prestasi belajar). Dalam hubungan dengan persamaan aris regresi linier sederhana dan berganda, nilai $\mathrm{R}^{2}$ dapat diketahui menggunakan spss versi 20.0 dengan hasil sebagai berikut :

Tabel 4.12

Koefisien Determinasi Berganda $\left(R^{2}\right)$

\begin{tabular}{|c|c|c|c|c|c|}
\hline \multicolumn{6}{|c|}{ Model Summary } \\
\hline Model & $\mathrm{R}$ & R Square & $\begin{array}{l}\text { Adjusted R } \\
\text { Square }\end{array}$ & $\begin{array}{c}\text { Std. Error of the } \\
\text { Estimate }\end{array}$ & Durbin-Watson \\
\hline 1 & $.586^{a}$ & .343 & .320 & 4.55955 & 2.164 \\
\hline
\end{tabular}

a. Predictors: (Constant), MOTIVASI, MINAT 
Pada Tabel 4.12 tersebut diperoleh nilai ${ }^{2}=0,343$ atau 34,3\% yang artinya bahwa besarnya kontribusi variabel X1 yaitu minat belajar dan X2 yaitu motivasi belajar terhadap variabel $\mathrm{Y}$ yaitu prestasi belajar adalah sebesar 34,3\% dan 65,7\% variabel Y (prestasi belajar) ditentukan oleh faktor lain.

\section{Gambaran Minat Belajar Siswa Kelas VIII SMPN 22 Sinjai.}

Berdasarkan hasil analisis data angket minat belajar matematika siswa Kelas VIII SMPN 22 Sinjai dengan 20 butir pernyataan dan jumla sampel sebanyak 60 siswa diperoleh skor tertinggi 69 , dan skor terendah yaitu 40 . Ada sebanyak 8 siswa dengan presentase $13 \%$ pada kategori minat belajar yang tinggi, 42 siswa dengan presentase $70 \%$ pada kategori minat belajar yang sedang, dan sebanyak 10 siswa dengan presentase $17 \%$ pada kategori minat belajar yang rendah.

Sejalan dengan pendapat Asnawati Matondang (2018) yang menyatakan bahwa minat sangat besar pengaruhnya terhadap prestasi belajar. Sejalan dengan penelitian Erlando bahwa minat belajar adalah perhatian, rasa suka,ketertarikan seseorang (siswa) terhadap belajar yang ditunjukkan melalui keantusiasan, partisipasi, dan keaktifan dalam belajar.

Sesuai dengan hasil penelitian siswa, menunjukkan bahwa secara keseluruhan minat belajar sedang lebih dominan sedang. dilihat dari dari angket dimana siswa melakukan usaha untuk menyelesaikan soal matematika dengan mengupayakan kondisi yang nyaman, tenang dan menyengkan dalam belajar. Aspek tinggi terlihat dari indikator bersemangat dalam mengikuti pelajaran matematika dan aspek rendah terdilihat dari aspek perhatian saat belajar.

\section{Gambaran Motivasi Belajar Siswa Kelas VIII SMPN 22 Sinjai.}

Berdasarkan hasil analisis data angket motivasi belajar matematika siswa Kelas VIII SMPN 22 Sinjai dengan 20 butir pernyataan dan jumla sampel sebanyak 60 siswa diperoleh bahwa tingkat motivasi belajar siswa Kelas VIII SMPN 22 Sinjai pada kategori tinggi sebanyak 8 siswa dengan persentase 14\%, pada kategori sedang sebanyak 41 siswa dengan presentase $68 \%$ dan pada kategori rendah sebanyak 11 siswa dengan presentase $18 \%$.

Adapun hasil penelitian yang dilakukan oleh Roida Eva Flora Siagian, melakukan penelitian pada tahun 2016, berdasarkan hasil penelitian menunjukkan terdapat pengaruh minat dan motivasi belajar terhadap prestasi belajar fisika pada siswa Kelas XI IPA SMA Negeri 1 Galing Kabupaten Sambas dengan nilai koefisien determinasi sebesar 0,46 yang menunjukkan bahwa $46 \%$ prestasi belajar fisika siswa dipengaruhi oleh minat dan motivasi belajar sedangkan siswa sebesar 54\% dipengaruhi oleh variable lain yang tidak termasuk dalam penelitian ini

Berdasarkan dengan hasil penelitian siswa, menunjukkan bahwa secara keseluruhan motivasi belajar siswa lebih dominan pada kategori sedang dimana siswa melakukan usaha 
untuk menyelesaikan soal matematika tetapi saat mengalami kesulitan belajar, siswa tetap melakukan upaya tetapi tidak semaksimal siswa yang memiliki motivasi belajar yang tinggi. Di mana siswa lebih tekun dan antusias dalam menyelesaikan soal matematika walaupun mengalami kendala pada saat proses penyelesaian.

\section{Gambaran Prestasi Belajar Matematika Siswa Kelas VIII SMPN 22 Sinjai.}

Berdasarkan hasil analisis data angket minat belajar matematika siswa Kelas VIII SMPN 22 Sinjai dengan 20 butir pernyataan dan jumla sampel sebanyak 60 siswa diperoleh sebanyak 13 siswa dengan persentase 22\% pada kategori tinggi, sebanyak 43 siswa dengan presentase $72 \%$ kategori sedang, dan pada kategori rendah sebanyak 4 siswa dengan presentase $6 \%$. Secara dominan siswa berada pada kategori prestasi belajar sedang. Pada penelitian ini nilai prestasi belajar diambil nilai matematika semester genap 2019/2020 sehingga dari nilai tersebut dapat menggambarkan tingkat pemahaman siswa terhadap pelajaran matematika. Prestasi belajar siswa dilihat dari segi psikomotornya atau keterampilan 43 siswa berada pada prestasi belajar sedang.

Sejalan dengan hasil penelitian yang telah dilakukan oleh Rifka Ulfa dkk (2018) menjelaskan bahwa berdasarkan pengkategorian tingkat prestasi belajar berada pada kategori sangat tinggi yakni mencapai 34,29\%.

Berdasarkan hasil penelitian, diperoleh data nilai semester siswa dengan nila rata-rata yaitu 79,50 dan berada pada kategori sedang. dapat diartikan bahwa prestasi belajar matematika siswa berada pada kategori sedang dan masih kurannya siswa memiliki prestasi belajar matematika yang tinggi.

\section{Model Regresi Minat Belajar Terhadap Prestasi belajar Matematika Siswa SMPN 22 Sinjai.}

Berdasarkan hasil analisis regrsi diperoleh data $a=47,834$ dan nilai $b=0,125$ sehingga persamaan regresinya adalah $\mathrm{Y}=47,834+0,598 \mathrm{X} 1$. Dari hasil data diketahui bahwa minat belajar dan prestasi belajar memiliki hubungan positif karena nilai b lebih besar dari $0(0,598>0)$ yang artinya jika nilai X1 dinaikkan 1 satuan maka nilai Y akan meningkat sebesar 47,834 satuan. Adapun besarnya konstribusi atau sumbangan minat belajar terhadap prestasi belajar yaitu 28,3\% dan 71,7\% ditentukan oleh faktor lain.

Pada penelitian yang dilakukan Asnawati Matondang yang menyatakan bahwa minat sangat besar pengaruhnya terhadap prestasi belajar apabila siswa yang memiliki minat terhadap suatu pelajaran dan mempelajarinya dengan sungguh-sungguh karena adanya daya tarik baginya dan minat belajar anak adalah suatu ketertarikan atau kecenderungan untuk memperoleh prestasi belajar, dan minat belajar dapat mempengaruhi prestasi belajar. 
Berdasarkan dengan hasil peneliatian, menunjukkan bahwa minat belajar dan prestasi belajar memiliki hubungan positif. Yang artinya Semakin tinggi minat belajar siswa maka prestasi belajar siswa akan meningkat, dan begitupun sebaliknya.

\section{Model Regresi Motivasi Belajar Terhadap Prestasi belajar Matematika Siswa SMPN 22 Sinjai.}

Berdasarkan hasil analisis regrsi diperoleh data $\mathrm{a}=57,473$ dan nilai $\mathrm{b}=0,398$ sehingga persamaan regresinya adalah $\mathrm{Y}=57,473+0,398 \mathrm{X} 2$. Dari hasil data diketahui bahwa motivasi belajar dan prestasi belajar memiliki hubungan positif karena nilai b lebih besar dari $0(0,398>0)$ yang artinya jika nilai X2 dinaikkan 1 satuan maka nilai Y akan meningkat sebesar 57,473 satuan. Adapun besarnya konstribusi atau sumbangan motivasi belajar terhadap prestasi belajar yaitu $15,9 \%$ dan $84,1 \%$ ditentukan oleh faktor lain.

Pada penelitian yang dilakukan Sanjaya yang mengatakan bahwa motivasi belajar berfungsi sebagai pendorong seseorang dalam nelakukan aktivitas belajar di mana siswa yang mempunyai prestasi belajar yang tinggi cenderung memiliki dorongan untuk belajar yang tinggi. Menurut Sardiman mengatakan bahwa motivasi belajar merupakan faktor psikis yang mampu menghadirkan rasa senang, gairah dan semangat untuk belajar.

Berdasarkan dengan hasil peneliatian, menunjukkan bahwa motivasi belajar dan prestasi belajar memiliki hubungan positif. Semakin tinggi motivasi belajar siswa maka prestasi belajar siswa akan meningkat, dan begitupun sebaliknya.

\section{Model Regresi Minat Belajar dan Motivasi Belajar Terhadap Prestasi belajar Matematika Siswa SMPN 22 Sinjai.}

Berdasarkan hasil analisis regrsi diperoleh data a $=38,301$ dan nilai ${ }^{b_{1}}=0,508$ dan nilai ${ }^{b_{2}}=$ 0,259 sehingga persamaan regresinya adalah $\mathrm{Y}=38,301+0,508 \mathrm{X} 1+0,259 \mathrm{X} 2$. Dari hasil data diketahui bahwa hubungan antara variabel bebas $\mathrm{X} 1$ minat belajar dan variabel terikat $\mathrm{Y}$ prestasi belajar yaitu konstan adalah berkorealasi positif atau memiliki hubugan positif antara minat belajar dan prestasi belajar. Dan untuk hubungan antara variabel bebas X2 motivasi belajar dan variabel terikat Y prestasi belajar yaitu kostan adalah berkorelasi positif atau memiliki hubungan positif antara motivasi belajar dan prestasi belajar. Yang artinya bahwa variabel bebas yaitu minat belajar dan motivasi belajar secara serentak atau bersama-sama memiliki hubungan positif terhadap variabel $\mathrm{Y}$ atau prestasi belajar. Adapun besarnya konstribusi atau sumbangan secara serentak atau bersamasama antara minat belajar dan motivasi belajar terhadap prestasi belajar yaitu 34,3\% dan 65,7\% ditentukan oleh faktor lain.

Sejalan dengan hasil penelitian yang dilakukan oleh Ira Nofita Sari, Dwi Fajar Saputri dan Sasmita menjelaskan bahwa terdapat pengaruh minat dan motivasi belajar terhadap prestasi belajar fisika pada siswa Kelas XI IPA SMA Negeri 1 Galing Kabupaten Sambas dengan nilai koefisien determinasi sebesar 0,46 yang menunjukkan bahwa $46 \%$ prestasi belajar fisika siswa dipengaruhi oleh minat dan motivasi belajar sedangkan siswa sebesar 54\% dipengaruhi oleh variable lainyang tidak termasuk dalam penelitian ini 
Berdasarkan dengan hasil penelitian, menunjukkan bahwa variabel bebas yaitu minat belajar dan motivasi belajar secara serentak atau bersama-sama memiliki hubungan positif terhadap variabel $\mathrm{Y}$ atau prestasi belajar. Artinya, Semakin tinggi minat belajar dan motivasi belajar siswa maka prestasi belajar siswa akan meningkat, dan begitupun sebaliknya. Minat belajar memberikan ketertarikan tersendiri dan rasa senang dalam diri siswa untuk belajar, siswa dengan belajar yang tinggi lebih tinggi memiliki tujuan belajar yang tinggi. Begitupun, siswa yang memiliki motivasi belajar yang tinggi cenderung memiliki tujuan belajar yang juga tinggi denga menghadirkan semangat serta dorongan untuk trus belajar. Oleh karena itu, mereka melakukan usaha dalam belajar agar mendapat prestasi belajar yang baik.

\section{KESIMPULAN}

Berdasarkan hasil penelitian dan pembahasan sebelumnya, maka dapat diperoleh kesimpulan sebagai berikut: (1) Berdasarkan hasil angket minat belajar matematika siswa Kelas VIII SMPN 22 Sinjai, dapat dilihat bahwa minat belajar siswa dominan pada kategori sedang, dengan rata-rata diperoleh 52,917. Diperoleh skor tertinggi 69, dan skor terendah yaitu 40. (2) Berdasarkan hasil angket motivasi belajar matematika siswa kelas VIII SMPN 22 Sinjai, dapat dilihat bahwa motivasi belajar siswa dominan pada kategori sedang, dengan rata-rata diperoleh 55,3. Diperoleh skor tertinggi 71 dan skor terendah 41. (3) Dari hasil dokumentasi prestasi belajar dengan jumla siswa 60 kelas VIII SMPN 22 Sinjai, dari data yang diperoleh bahwa prestasi belajar matematika siswa berada pada kategori sedang, dengan nilai rata-rata dengan rata-rata 80. Diperoleh skor tertinggi 95 dan skor terendah 72. (4) Dari hasil penelitian, adanya hubungan positif antara minat belajar terhadap prestasi belajar matematika siswa SMPN 22 Sinjai, artinya semakin tinggi minat belajar siswa maka prestasi belajar siswa akan meningkat. (5) Dari hasil penelitian, adanya hubungan positif antara motivasi belajar terhadap prestasi belajar matematika siswa SMPN 22 Sinjai, artinya semakin tinggi motivasi belajar siswa maka prestasi belajar siswa akan meningkat. (6) Dari hasil peneltian, menunjukkan bahwa variabel bebas yaitu minat belajar dan motivasi belajar secara serentak atau bersama-sama memiliki hubungan positif terhadap variabel $\mathrm{Y}$ atau prestasi belajar. Artinya, Semakin tinggi minat belajar dan motivasi belajar siswa secara bersama-sama maka prestasi belajar siswa akan meningkat, dan begitupun sebaliknya.

\section{DAFTAR PUSTAKA}

Djamarah. Syaiful Bahri. (2002). Psikologi Belajar. Jakarta: Rineka Cipta. Elfachmi. Amin Kuneifi. (2016). Pengantar Pendidikan. Jakarta: Erlangga. 
Heriyati. (2017). Pengaruh Minat dan Motivasi Belajar Terhadap Prestasi Belajar Matematika. Jurnal Formatif, 7(1).

Lestari .Karunia Eka \& Mokhammad Ridwan Yudhanegara. (2015). Penelitian Pendidikan Matematika. Bandung: PT Refika Aditama.

Mustajab. Moh. Zaiful Rosyid. dan Aminol Rosid Abdullah. (2019). Prestasi Belajar. Malang: Literasi Nusantara Abadi.

Nurhidayah. Dwi Avita. (2015). Pengaruh Motivasi Berprestasidan Gaya Belajar Terhadap Prestasi Belajar Siswa pada Mata PelajaranMatematika SMP. Jurnal Dimensi Pendidikan dan Pembelajaran, 3(2).

Priyanto, Duwi. (2012). Belajar Cepat Olah Data Statistik dengan SPSS. Yogyakarta: Andi Yogyakarta.

Sardiman. (2012). Interaksi \& Motivasi Belajar. Jakarta: Rajawali Pers.

Simarmata. Ester Julinda. (2017). Upaya Meningkatkan Aktifitas dan Hasil Belajar Siswa Pada mata Pelajaran Matematika dengan Pendekatan Kontekstual (CTL) di Kelas V SDN 060959 Belawan. ESJ, 7(3).

Sirait. Erlando Doni. (2016). Pengaruh Minat Belajar Terhadap Prestasi Belajar Matematika. Jurnal Formatif, 6(1).

Slameto. (2010). Belajar \& Faktor-Faktor yang Mempengaruhi. Jakarta: Rineka Cipta.

Syah, Muhibbin. (1995). Psikologi Pendidikan. Bandung: PT. Remaja Rosdakarya.

Uno, Hamzah B. (2013). Teori Motivasi dan Pengukurannya. Jakarta: Bumi Aksara. 